\title{
緩傾斜堤への波の打ち上げ高さ及び遡上 特性に関する現地観測値の基礎的検討 \\ THE BASIC EXAMINATION OF FIELD OBSERVATION VALUES OF WAVE RUN-UP HEIGHT FOR GENTLE-SLOPE SEA DIKE
}

\author{
高橋敏彦 ${ }^{1} \cdot$ 沼田 淳 $^{2}$ \\ Toshihiko TAKAHASHI and Atsushi NUMATA \\ '正会員 博(工) 東北工業大学講師 工学部土木工学科 (7982-8577 仙台市太白区八木山香澄町35番1号) \\ ${ }^{2}$ 正会員 工博 東北工業大学教授 工学部土木工学科（干982-8577 仙台市太白区八木山香澄町 35 番1号）
}

\begin{abstract}
Field observations of wave run-up height for Gentle-slope sea dike facing the Bay of Ishinomaki were carried out.The correlations between the representative waves were obtained as follows : $\mathrm{H}_{1 / 10}=$ $1.265 \mathrm{H}_{1 / 3}, \mathrm{H}_{1 / 3}=1.590 \overline{\mathrm{H}}$ in offshore waves and $\mathrm{R}_{1 / 10}=1.146 \mathrm{R}_{1 / 3}, \mathrm{R}_{1 / 3}=1.263 \overline{\mathrm{R}}$ in wave run-up heights and $V_{1 / 10}=1.122 V_{1 / 3}, V_{1 / 3}=1.234 \bar{V}$ in wave uprush velocity. Frequency distribution of wave run-up heights and wave uprush velocity on this Gentle-slope sea dike were obtained. The values of rerative run-up heights $(\mathrm{R} / \mathrm{Ho})$ tended to decrease, as wave deep steepness $(\mathrm{Ho} / \mathrm{Lo})$ was bigger, and as relative depth (hi/Lo,hi:water depth at toe of sea dike) was smaller.
\end{abstract}

Key Words : Gentle-slope sea dike, field observation, wave run-up height,wave uprush velocity

\section{1.はじめに}

遡上波に関する現地観測は，たとえば首藤 ${ }^{11}$ ，久 宝ら ${ }^{21}$, Waddell,E. ${ }^{3)}$,小川 ( $^{4)}$, 水口ら ${ }^{51}$, 久保田 $ら^{6)}$ ，等多くの研究が行われているが，多くは自然 海浜に対しての現地調查である。緩傾斜堤が注目さ れ始めて日が浅く, また適切な観測地点の選定が難 しいため現地観測に関する研究例は少ない7)。しかし， 現地の緩傾斜堤への波の打ち上げ高さを推定するた めには，現地調査によって実際の波の打ち上げ高さ 及び遡上特性を把握する事が重要である。著者らは， できるだけ多くの実測値を蒐集蓄積するため，宮城 県北部に設置されている緩傾斜堤への波の打ち上げ 高さに関する現地観測を行っている。本研究では， 2ヶ年間の波の観測值を基に, 波の打ち上げ高さ及び 遡上特性に関する基礎的検討を行う事を目的とした。

\section{2. 現地調査概要}

波の打ち上げ高さに関する現地観測は，宮城県北 部に設置されている緩傾斜堤を対象とした。場所は, 宮城県桃生郡矢本町の大曲海岸で石巻湾内に位置し ている。図-1は，現地観測地の概略図を示している。

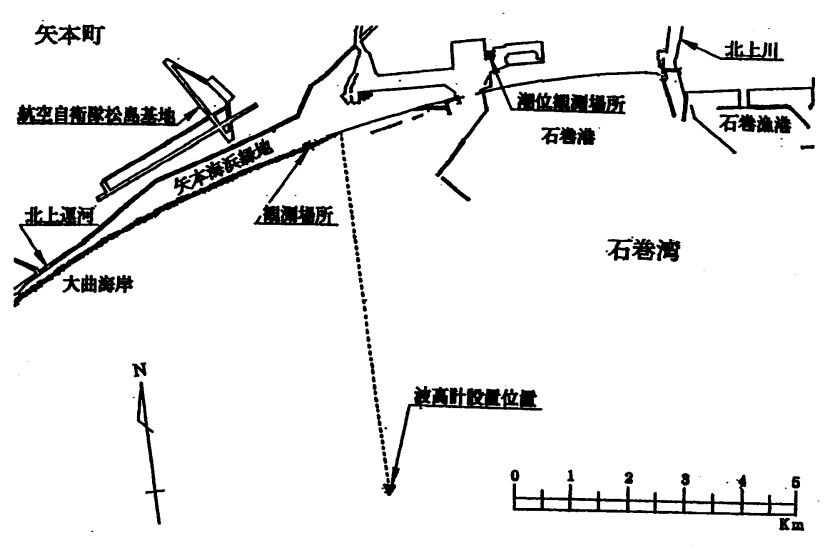

図-1 現地観測地の概略図

緩傾斜堤は、1個のブロックの空隙率が約 $15 \%$ の 2 ブロ ックで構成されているが, 配列間の空隙を含めると 約22\%程度の空隙率を持つ4割勾配の緩傾斜堤である。

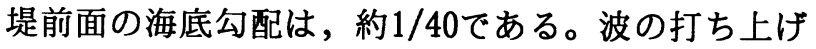
高さの観測は, 午前 8 時から午後 4 時までの毎偶数 時前後 10 分間（計 20 分間）ずつ1日 5 回行った。打ち 上げ高さ $(\mathrm{R}$ : 静水面からの鉛直高さ)は，のり面に0. $5 \mathrm{~m}$ 毎にマーキング及び $1 \mathrm{~m}$ 毎に鉄筋を設置して目視よ り読み取り，T.P.を基準に観測時の潮位補正を行っ て求めている。波先端移動速度は, 波の打ち上げ高さ の大きい波, 数十波についてストップウオッチを用 


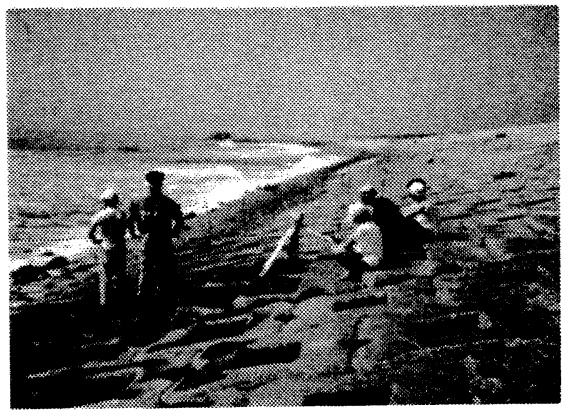

写真-1 現地観測風景

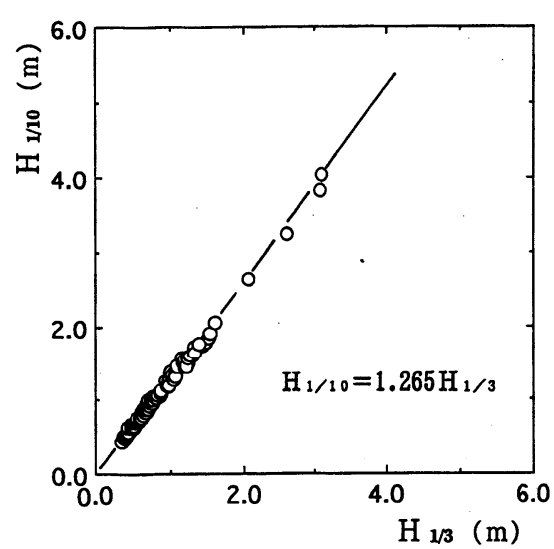

困-2(a) $\mathrm{H}_{1 / 10}$ と $\mathrm{H}_{1 / 3}$ の関係

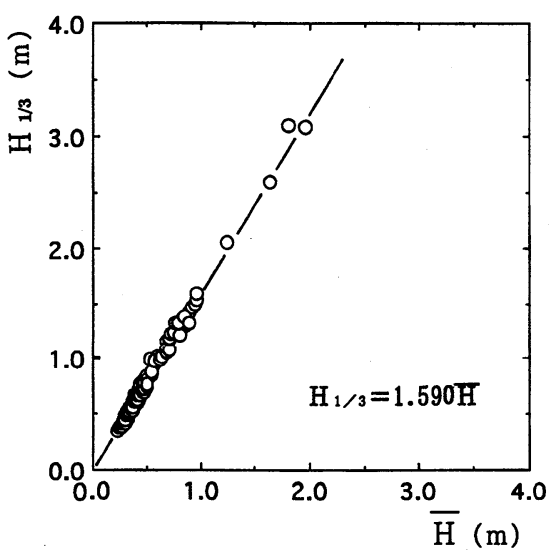

図-2(b) $\mathrm{H}_{1 / 3}$ と $\overline{\mathrm{H}}$ の関係

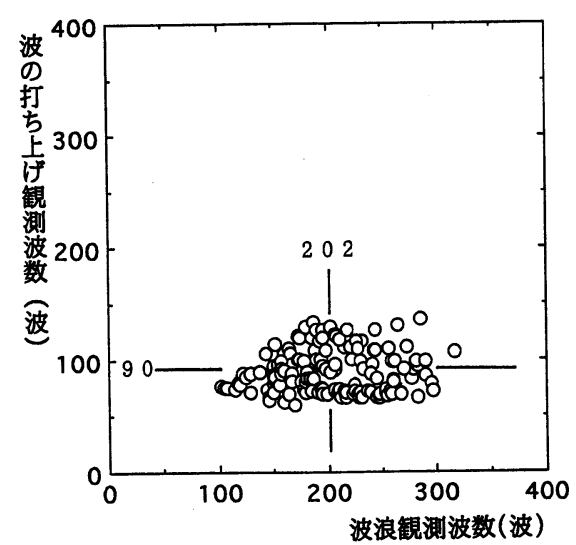

図-3(a) 波浪観測波数と波の打ち上げ観測波数

いて測定した。現地観測は，1996年7月8日〜11月28日 までと1997年9月3日〜11月4日までの 2 ケ年間計 31 日 間の143回である。写真-1は，1996年9月12日の観測 風景である。当日の沖波波形勾配は，0.0042〜0.00 64であり，相対水深(堤脚水深／沖波波長)は0または 0.01 となっており, 比較的稳やかで堤脚水深として は浅い方の観測日である。

観測值の波浪諸元と潮位は, 運輸省第二港湾建設 局石巻港事務所(波浪は観測地より沖合約 $6.5 \mathrm{~km}$, 設 置水深約 $20 m て ゙$ 観測)及び, 宮城県石巻港湾事務所

（観測地近くの港内で測定）の観測データを利用した。

\section{3. 波浪及び波の打ち上げ高さの出現確率}

\section{（1）波浪出現確率}

図-2(a),(b)は，波の打ち上げ高観測時 2 ケ年間 分の波高計設置位置における波高の代表值間の相関 図であり，いずれも $N=143$ 個である。図示のとうり $\mathrm{H}_{1 / 10}=1.265 \mathrm{H}_{1 / 3}, \mathrm{H}_{1 / 3}=1.590 \overline{\mathrm{H}}$ となり, LonguetHiggins $^{8)}$ が, Rayleigh分布と仮定して求めた值

$\left(\mathrm{H}_{1 / 10}=1.271 \mathrm{H}_{1 / 3}, \mathrm{H}_{1 / 3}=1.597 \overline{\mathrm{H}}\right)$ とほぼ同程度と なっている。

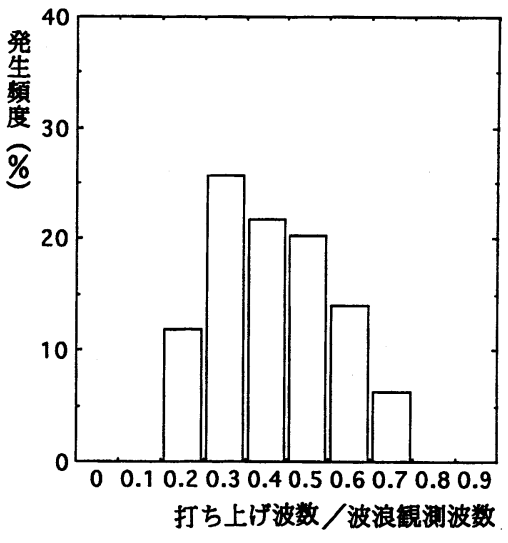

図-3(b) 打ち上げ波数/波浪観測波数の発生頻度

図-3(a)は，計20分間の波浪観測波数と波の打ち上 げ観測波数の関係を図示したものである。波浪観测 地点における観測波数102〜316波に対して波の打ち 上げ観測波数は60〜133波となっており，それそれの 平均值は，202波と 90 波となっている。図-3(b)は， 横軸に波浪観測波数に対する波の打ち上げ観测波数 の割合を，縦軸はその発生頻度（\%）を示したもの である。波浪観測波数に対して波の打ち上げ観測波 数は, 約 $25 \%$ 75\%に減少している。全観測結果に おいて最も観測頻度の多かったのは, 0.3 ( 3 割台) であり，平均值は0.44である。波浪観測波数の約半 数弱の波数に対して，打ち上げ高さの観測を行って いることになる。

久保田ら 9 の種々の海岸での遡上波に関する現地 観測によると，遡上斜面前面で測定した入射波に対 して遡上波の波の数は $10 〜 60 \%$ の減少を示している。 また豊島 ${ }^{7)}$ は，波の打ち上げ高観測において観測20 分間の沖波波数が150〜260波に対して, 波の打ち上 げ高の波数が70〜120波となっていると報告している。 これらのことから, 今回の波浪観測波数と波の打ち 上げ観測波数の関係は, 既往の現地観測結果とほぼ 同傾向を示していることがかる。 


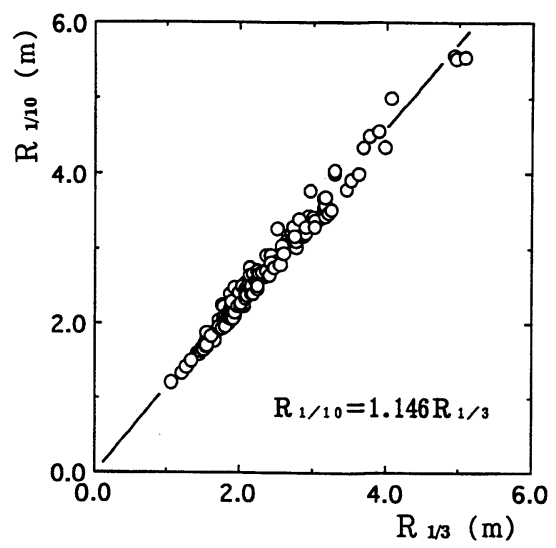

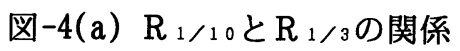

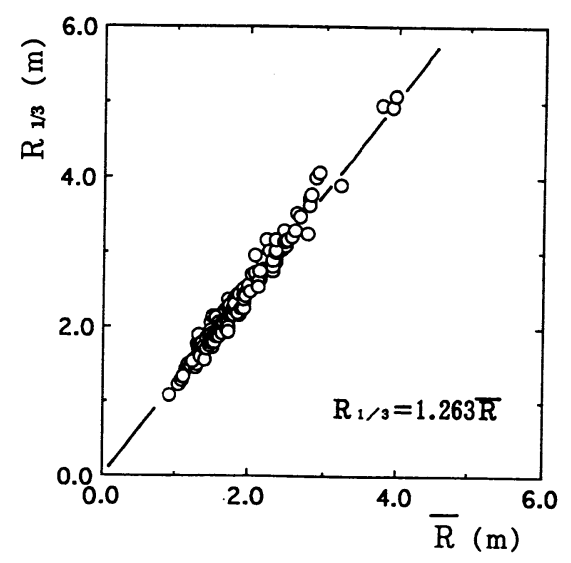

図-4(b) $R_{1 / 3}$ と $\bar{R}$ の関係

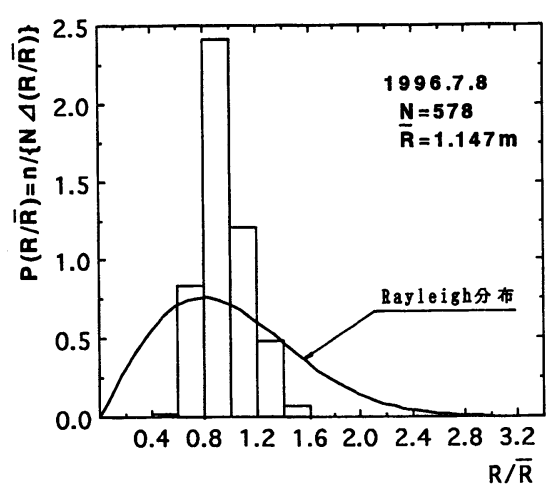

図-5(a) 波の打ち上げ高の 確率密度分布

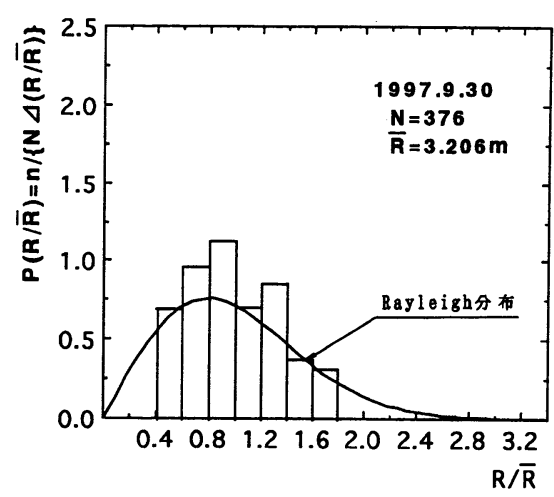

図-5(b) 波の打ち上げ高の 確率密度分布

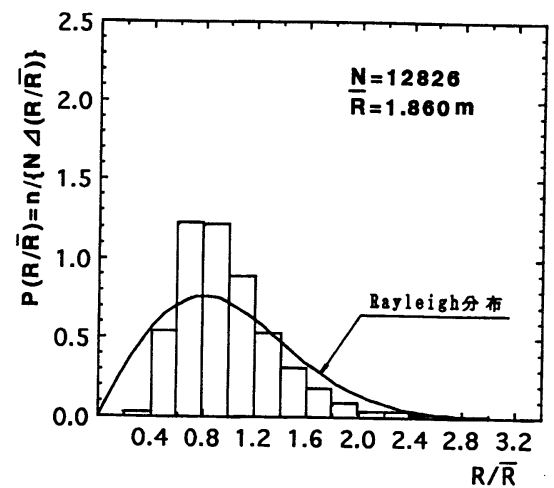

図-5(c) 波の打ち上げ高の 確率密度分布
（2）波の打ち上げ高さの頻度分布特性

a）代表打ち上げ高さ間の関係

図-4(a)，(b)は，波の打ち上げ高Rの代表值 $\left(R_{1} / 10 ，\right.$ $\left.\mathrm{R}_{1 / 3}, \overline{\mathrm{R}}\right)$ 間の関係を示したものである。図-2で示し た代表波高間の $\mathrm{H}_{1 / 10}$ と $\mathrm{H}_{1 / 3}, \mathrm{H}_{1 / 3}$ と藏より幾分ばら つきがあるが， $R_{1 / 10}=1.146 R_{1 / 3}, R_{1 / 3}=1.263 \bar{R}$ 関 係が認められる。この関係式の傾きは，代表波高間 のそれそれの傾きに比べて小さい值となっている。

b) 波の打ち上げ高さの頻度分布

次に, 波の打ち上げ高さの確率密度分布について 検討してみた。

図-5(a), (b)は，現地観測2年年間の中で平均打ち上 げ高さが最も小さいケースと最も大きいケースの波 の打ち上げ高さの観測值Rを，平均打ち上げ高さ華で 無次元化した值 $\mathrm{R} / \overline{\mathrm{R}}$ の確率密度を柱状グラフで示した 例である。図中の実線は, Rayleigh分布 ${ }^{10)}$ 曲線を示 している。(a)は，1996年7月8日の観測值であり，平

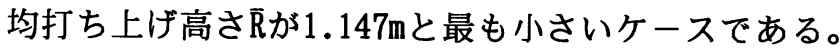
波の打ち上げ高の測定波数 $\mathrm{N}=578$ 波は，1日の測定波 数としては比較的多い方であるが，打ち上げ高の発 生割合が $R / \overline{\mathrm{R}}=0.6 \sim 1.2$ 集中しており, 特に $\mathrm{R} / \overline{\mathrm{R}}=0$. 8〜1.0の值が突出している。このケースは, 全ケー
スの中でも狭い範囲に集中している特異な例である。 これは，比較的波高の小さい揃った波が，ほとんど 非砕波で遡上したため平均值付近の狭い範囲に集中 したと思われる。(b)は，1997年9月30日の観測值で ある。当日は, 台風接近中で海が荒れている状態の 観測であり，平均打ち上げ高さが $3.206 \mathrm{~m}$ と最も高い 值を示した例である。測定波数 $\mathrm{N}=376$ 波と (a)よりデ 一ダ少ないにも関わらず， $\mathrm{R} / \overline{\mathrm{R}}=0.4 \sim 1.8$ の比較的広 い範囲に分布しており，ばらつきはあるもののRayl eigh分布と同じような傾向が伺われる。

図-5(c)は，2午年間の全観測データ $\mathrm{N}=12,826$ 波を 柱状グラフで示したものである。平均打ち上げ高さ は，1.860mである。打ち上げ高さの小さい波を無視 しているため， $\mathrm{R} / \overline{\mathrm{R}}<0.4(\mathrm{R}<0.74 \mathrm{~m})$ の波はほとんど観 測されていない。これらのことを考慮に入れると打 ち上げ高の確率密度分布は, Rayleigh分布とほほ同 様と考えても良いように思われる。

\section{4 . 波先端移動速度}

\section{（1）波先端移動速度の定義}

著者等 ${ }^{111}$ は,緩傾斜堤の波の相対打ち上げ高さR/ Hoをsurf similarity parameter $\xi$ のべキ乗に比例 

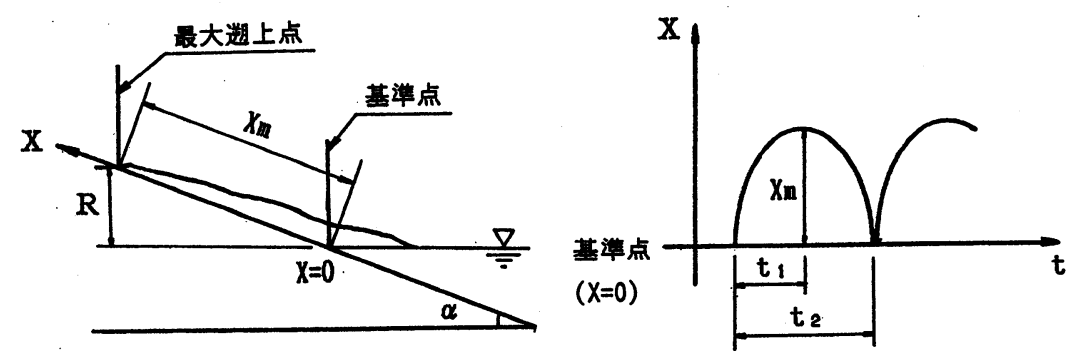

図-6 波の打ち上げ高さの模式図

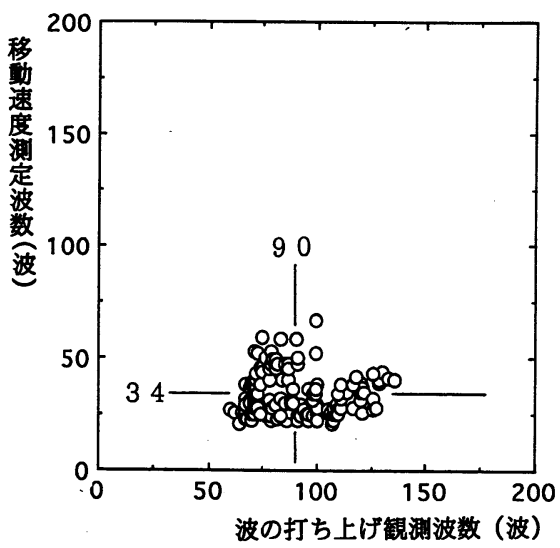

図-7 波の打ち上げ観測波数と波先端移動速度測定波数

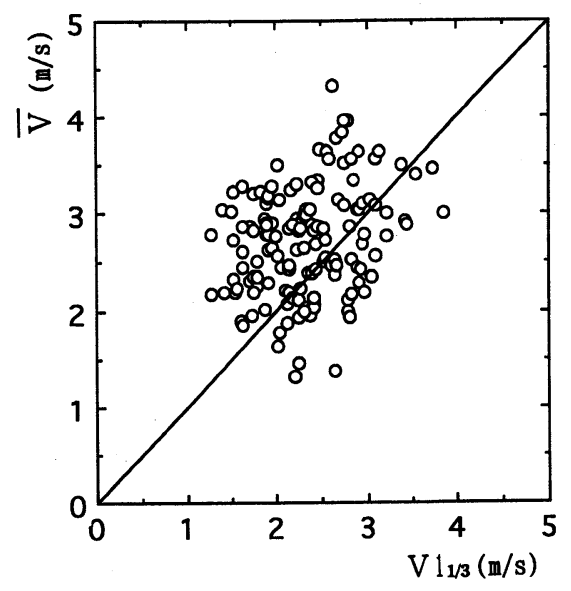

図-8 波先端移動速度 $\overline{\mathrm{V}}$ と $\mathrm{V} 1_{1 / 3}$ の比較

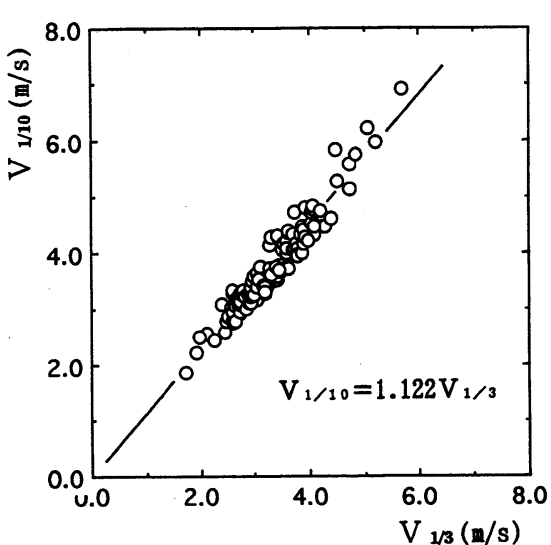

図-9（a）波先端移動速度 $V_{1 / 10}$ と $\mathrm{V}_{1 / 3}$ の比較

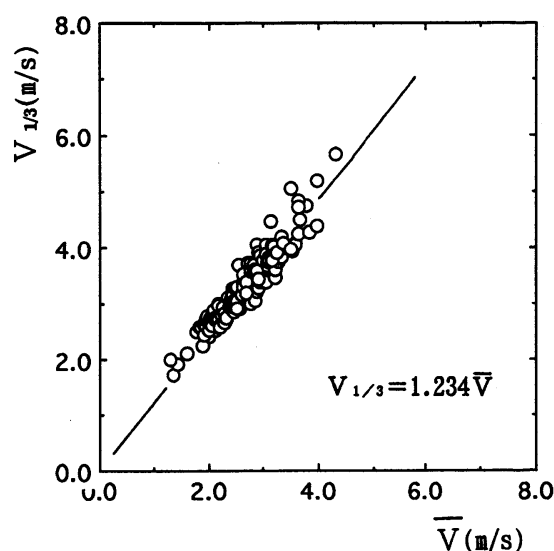

図-9(b) 波先端移動速度 $V_{1 / 3}$ と $\overline{\mathrm{V}}$ の比較
すると考え，その比例定数とべキ数を波の周期 $\mathrm{T}$ と打 ち上げ高さRから求めた波先端移動速度Vを用いたRe ynols数と関連づけて実験式を提案している。本節で は，TとRから求めたVと現地観測値との整合性を調べ るとともに，その統計量について考察した。

図-6は,波の打ち上げ高さの模式図である。実測の $\mathrm{V}$ は，波先端がXmの斜面距離を通過した時間 $\mathrm{t}_{1}$ をスト ップウォッチで測定し, 式(1)より求めた。一方,式 (2)は,TとRを用いて求めたVの定義式である。

$$
\begin{aligned}
\mathrm{V} & =\mathrm{Xm} / \mathrm{t}_{1}\left\{=2 \mathrm{R} / \sin \alpha \cdot 1 / \mathrm{t}_{2}\right\} \\
\mathrm{V} 1 & =2 \mathrm{R} / \mathrm{sin} \alpha \cdot 1 / \mathrm{T}
\end{aligned}
$$

$\mathrm{Xm}$ : 基準点 (学静水面)から波の打ち上げ高さまでの斜 面距離 (m)

$t_{2}: t_{1}$ の2倍の時間 $(\mathrm{sec}), \alpha$ : 法面角度

図-7は, 観測20分間における波の打ち上げ高観測 波数と波先端移動速度測定波数の関係を図示したも のである。波の打ち上げ高観測波数60〜133波に対し て21〜67波であり，それそれの平均值は，90波と 34 波である。すなわち，打ち上げ高さの約 $1 / 3$ 最大波に ついて波先端移動速度を測定していることになると 思われる。

図-8は，実測波先端移動速度の平均值 $(\bar{V})$ と，式
(2)において $R_{1 / 3} ， \mathrm{~T}_{1 / 3}$ を用いて計算したV1 $1_{1 / 3}$ の值 の比較図である。図より $\bar{V} の$ 方が幾分大きい值を示し， ばらつきも大きいが，全体的には両者とも同程度の 值とみなしてよいように思われる。このことから， 平均波先端移動速度 $(\overline{\mathrm{V}})$ は，波の打ち上げ高さ（R, $\left.{ }_{3}\right)$ ，入射波周期 $\left(\mathrm{T}_{1 / 3}\right)$ より求めることが可能と考 えられる。ただし，この場合の平均波先端移動速度 は，打ち上げ高観測波数のほぼ $1 / 3$ 最大值に対応する 遡上波である。

\section{（2）波先端移動速度の頻度分布 \\ a）代表波先端移動速度間の関係}

図-9(a), (b)は，実測波先端移動速度Vの代表值 $\left(\mathrm{V}_{1 / 10}, \mathrm{~V}_{1 / 3}, \overline{\mathrm{V}}\right)$ の関係を示したものである。図-9 より $\mathrm{V}_{1 / 10}=1.122 \mathrm{~V}_{1 / 3}, \mathrm{~V}_{1 / 3}=1.234 \overline{\mathrm{V}}$ の関係が認め られる。両式の傾きは，観測波高，打ち上げ高の各 代表間の関係式の傾きに比べ小さい值を示し, 最も 1 に近い值となっている。

\section{b) 波先端移動速度の頻度分布}

図-10(a),(b)は，現地観測回数143回のうち平均波 先端移動速度可が最も小さいケースと最も大きいケー 


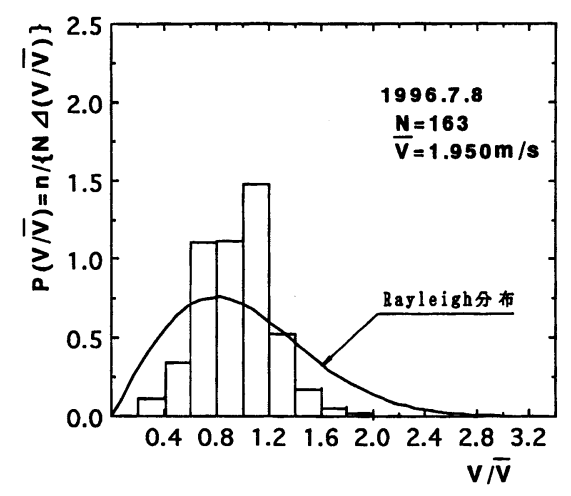

図-10（a）波先端移動速度の 確率密度分布

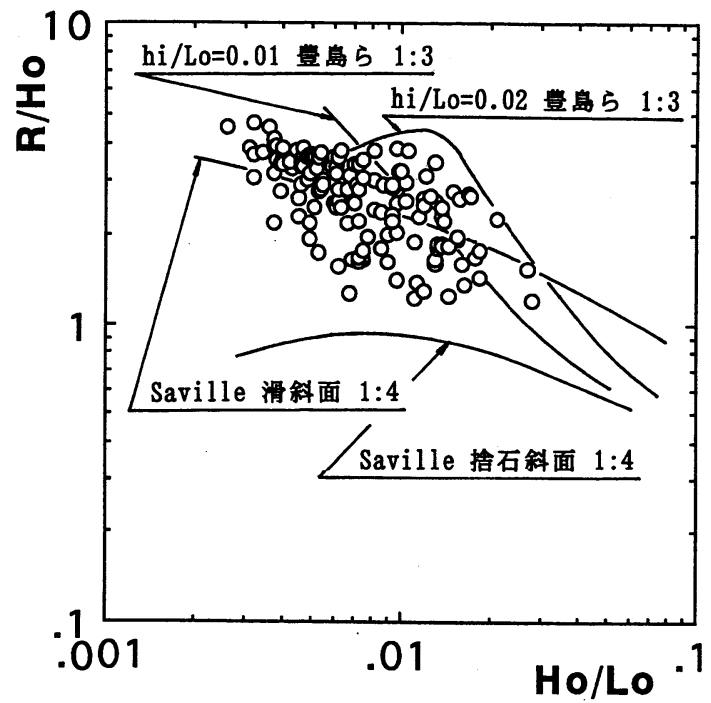

図-11(a) R/HoとHo/Loの関係（1/10最大值）

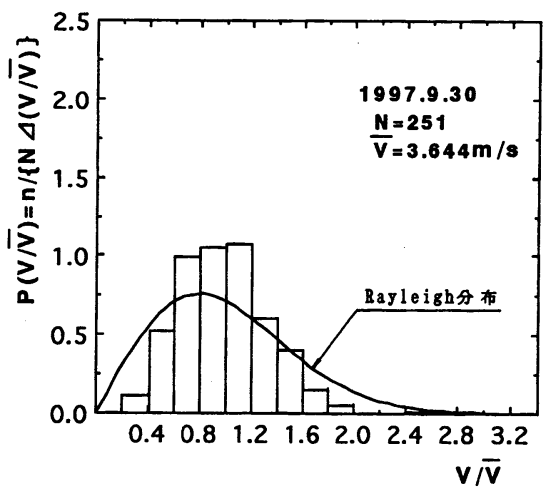

図-10（b）波先端移動速度の 確率密度分布

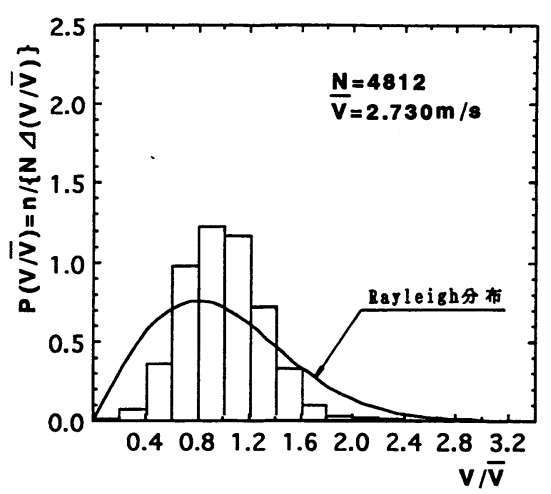

図-10(c) 波先端移動速度の 確率密度分布

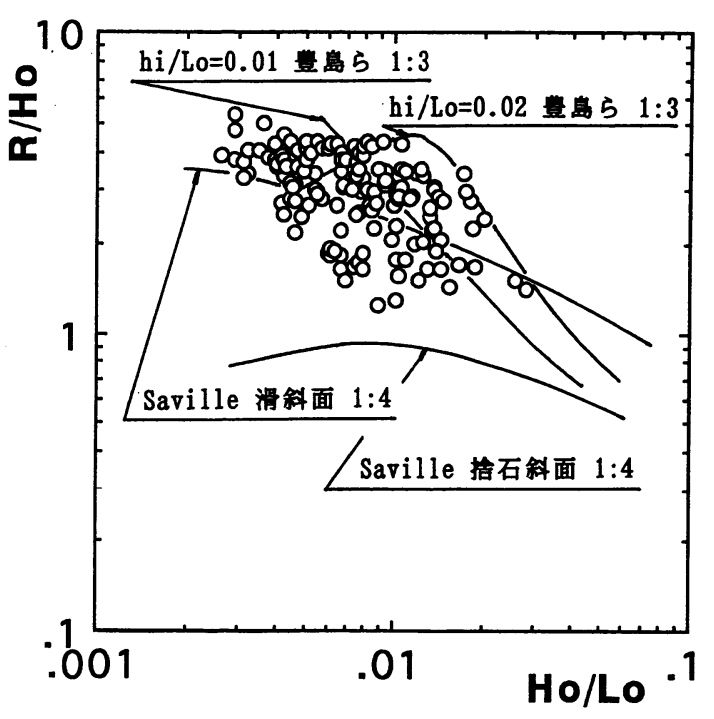

図-11(b) R/HoとHo/Loの関係（1/3最大値）

れる。

スの波先端移動速度VをVで無次元化した值の確率密 度を柱状グラフで示した例である。図中の実線は， Rayleigh分布を表している。(a)は図-5(a)と同じ19 96 年7月 8日の観測值で測定波数 $\mathrm{N}=163, \overline{\mathrm{V}}=1.950 \mathrm{~m} / \mathrm{s} て ゙$ ある。Rayleigh分布に比べ分布幅が狭く，図-5(a)と 同程度の分布幅となっている。(b)は，図-5(b)と同 じ1997年9月30日の観測值で $\bar{V}=3.644 \mathrm{~m} / \mathrm{s}$ で (a)の約 1. 9倍となっている。図-5(b)と同程度の分布形状を示 し，(a)よりはRayleigh分布に近づいている。

図-10(c)は，2ケ年間の全データ $\mathrm{N}=4,812$ 波の波先端 移動速度を柱状グラフで示したもので，平均波先端

移動速度 $\overline{\mathrm{V}}=2.730 \mathrm{~m} / \mathrm{s}$ となっている。図中の $\mathrm{V} / \overline{\mathrm{V}}<0.4$ $(\mathrm{V}<1.09 \mathrm{~m} / \mathrm{s})$ と $\mathrm{V} / \overline{\mathrm{V}}>1.6(\mathrm{~V}>4.37 \mathrm{~m} / \mathrm{s})$ の波先端移動速度 はほとんど観測されていない。0.4以下の頻度が少な いのは，打ち上げ高の大きい波を対象としたためで あり,1.6以上の頻度が少ないのはその結果㰻大きい 值となり，V/V̄が相対的に小さくなったためと考えら

\section{5. 相対打ち上げ高さと沖波波形勾配の関係}

図-11(a)(b)は， $H_{1 / 10}, H_{1 / 3}$ とR $R_{1 / 10}, R_{1 / 3}$ を用い て求めた相対打ち上げ高さ $(\mathrm{R} / \mathrm{Ho})$ と沖波波形勾配(H o/Lo)の関係を図示したものである。比較のために， Saville ${ }^{12)}$ の1/4勾配に対する滑面及び搭石斜面の実 験曲線と, 豊島 ${ }^{13)}$ らの1/3勾配の滑面に対する実験 曲線も示している。ただし, Savilleの実験曲線はhi /Ho(堤脚水深/沖波波高)が3.0以上での実験結果であ る。図-11(a)(b)ともR/Hoの值とばらつきの程度はほ ぼ同じで，観測值はSavilleの滑面曲線付近に分布し ている。豊島らのhi/Lo=0.01,0.02と比較すると，観 測值の方が全体的に小さめの值を示している。これは、

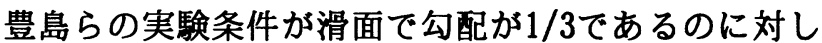

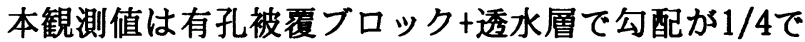
あるためと思われる。

図-12は，有義波を用いhi/Loをパラメーターと してR/HoとHo/Loの関係を拡大図示したものである。 


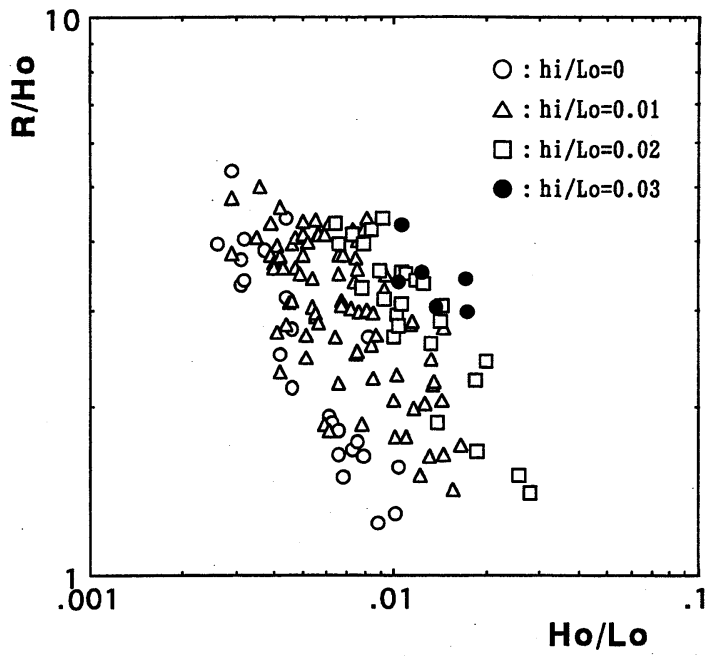

困-12 R/HoとHo/Loの関係

かなりばらつきはあるが，R/Hoの值はHo/Loが大きい ほど,またhi/Loが小さいほど小さくなる傾向が認め られる。

\section{6. おわりに}

本研究では，2ヶ年間の波の観測值を基に，波の打 ち上げ高さ及び遡上特性に関する基礎的検討を行っ た。主要な結論をまとめると次のとおりである。

（1）波浪観測地点における代表波高間の関係は, $\mathrm{H}_{1 / 10}=1.265 \mathrm{H}_{1 / 3}, \mathrm{H}_{1 / 3}=1.590 \overline{\mathrm{H}}$ となり, 波高出現確 率をRayleigh分布と仮定した值 $\left(\mathrm{H}_{1 / 10}=1.271 \mathrm{H}_{1 / 3}\right.$ ， $\left.\mathrm{H}_{1 / 3}=1.597 \overline{\mathrm{H}}\right)$ とほぼ同程度の值となってる。

（2）20分間の波浪観測波数102３16波に対して波 の打ち上げ観測波数は60〜133波となっており，波浪 観測地点における入射波に対して波の打ち上げ観測 波数は，約 $25 \%$ 75\%の減少を示した。

（3）代表遡上高さ間の関係は， $\mathrm{R}_{1 / 10}=1.146 \mathrm{R}_{1 / 3}$, $\mathrm{R}_{1 / 3}=1.263 \overline{\mathrm{R}}$ であり，また代表波先端移動速度間の 関係は, $\mathrm{V}_{1 / 10}=1.122 \mathrm{~V}_{1 / 3}, \mathrm{~V}_{1 / 3}=1.234 \overline{\mathrm{V}}$ となる。い ずれも代表波高間の傾きより小さい值となった。

（4）波の打ち上げ高さ $\mathrm{R} / \overline{\mathrm{R}}$ の頻度分布と波先端移動 速度 $\mathrm{V} / \overline{\mathrm{V}}$ の頻度分布は，ほぼ同様の分布形を示しR/R $=\mathrm{V} / \overline{\mathrm{V}}=0.4 \sim 1.6$ の発生頻度が大きい。0.4以下の頻度 が少ないのは，小さい遡上波を無視したためであり， $\mathrm{V} / \overline{\mathrm{V}}$ の1.6以上の頻度が少ないのは打ち上げ高の大き い波を対象としたため, $\overline{\mathrm{V}}$ が大きい值となりV/V̄が相 対的に小さくなったためと考えられる。

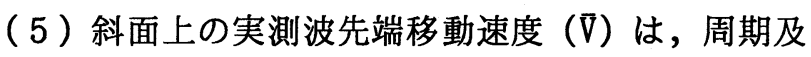
び波の打ち上げ高さの $1 / 3$ 最大值 $\left(\mathrm{T}_{1 / 3}, \mathrm{R}_{1 / 3}\right)$ 等を
用いて求めた計算値 $V_{1 / 3}\left(=2 \mathrm{R}_{1 / 3} / \sin \alpha \cdot 1 / \mathrm{T}_{1 / 3}\right)$ とほぼ対応することが示される。

（6）実測值はかなりばらついているが, 既往の実 験值とほぼ同程度の值を示し, hi/Loのパラメータは 打ち上げ高さに大きく影響を与えると思われる。

謝辞:本研究を行うにあたり,運輸省第二港湾建設局 石巻港事務所及び宮城県石巻港湾事務所より貴重な 資料を提供して頂いた。また,現地調査は当時東北工 業大学土木工学科の卒研生に協力して頂いた。ここ に記して謝意を表します。

\section{参考文献}

1）首藤伸夫 : 不規則波の打ち上げ高, 土木学会第23回年 次学術講演会講演概要集 II, pp.49-50, 1968 .

2）久宝雅史,遠藤茂勝：現地海岸における波の打ち上げ に関する一考察（第 2 報），土木学会第23回年次学術講 演会講演概要集 II,pp.51-52, 1968 .

3） Evans Waddell:自然海浜における打ち上げ波の特性 に関する現地観測, 第20回海岸工学講演会論文集, pp. 545-551, 1973.

4）小川由信,首藤伸夫：波打帯の水理特性について, 第 29回海岸工学講演会論文集, pp.135-139, 1982.

5）水口 優,苅部好伸, 堀田新太郎：現地海岸における 遡上波について, 第30回海岸工学講演会論文集, pp.10 9-113,1983.

6）久保田進,水口 優, 堀田新太郎, 竹澤三雄 : 急勾配前 浜海岸における遡上波の現地観測, 第35回海岸工学講 演会論文集, pp.118-122,1988.

7）豊島 修: 緩傾斜護岸工法, 第34回海岸工学講演会 論文集,pp.447-451, 1987.

8) Longuet-Higgins, M.S.:On the Statistical Distributions of the Heights of Sea Waves, Jour.Marine, Res., Vol. 9, No. 3, pp. 245-266, 1952.

9）久保田進,水口 優, 竹澤三雄 : 遡上 - 反射波分布の 予測モデル, 海岸工学論文集, 第39巻, pp.21-25,1992.

10）土木学会水理公式集例題集（昭和60年版）：第6編 海岸・港湾編,pp. 247-250,1985.

11）高橋敏彦,首藤伸夫,沼田 淳:緩傾斜堤への波の打 ち上げ高の一推定法, 海岸工学論文集, 第38巻, pp. 501$505,1991$.

12) Saville,T.Jr : Laboratory Investgation of Rubble-mound Breakwaters, Journal of the Waterways and Harbors Divison, ASCE, Vol.86, No. ww3, pp.151156, sept., 1960 .

13）豊島 修・首藤伸夫・橋本 宏: 海岸堤防への波の 打ち上げ高一海岸勾配 $1 / 20$-, 第12回海岸工学講演会 講演集,pp.180-185, 1965. 